\title{
A SUBSTANCIALIDADE DOS PROCEDIMENTOS OLIGÁRQUICOS NO BRASIL ENTRE 1995 E 1998: as análises de Faoro
}

\author{
Maria José de Rezende*
}

\begin{abstract}
Este estudo mapeia as reflexões de Raymundo Faoro, na segunda metade da década de 1990, com base em artigos e entrevistas publicados pelo autor na revista Carta Capital, acerca da continuidade ou não dos procedimentos políticos que reafirmavam as dificuldades de constituição de práticas mais duradouras na consolidação da democracia no país. A análise desses materiais jornalísticos, tomados como documentos, elucida alguns fundamentos dos embates travados, na década de 1990, por diversos segmentos sociais presentes na arena política. PALAVRAS-CHAVE: democracia, oligarquia, autoritarismo, mudança política, reformas.
\end{abstract}

A obra de Raymundo Faoro (1925-2003) Os donos do poder, publicada pela primeira vez no final da década de 1950, foi um marco nos debates acerca do padrão de domínio em vigor no país desde a colonização. Suas análises sobre o autoritarismo brasileiro foram fundamentais para a compreensão da complexidade do estado de exceção instaurado no país a partir de 1964. Sua militância política pela instauração do Estado de direito democrático no país, nas décadas de 1970 e 1980, somou-se a inúmeros outros esforços de representantes da sociedade civil organizada que lutavam pela revogação dos instrumentos de repressão e de controle implantados pela ditadura militar.

Em razão da vasta reflexão empreendida por Raymundo Faoro no decorrer de quase cinco décadas, esta resenha temática não tem como abarcar todas as nuanças de suas análises nem como se ater a todas as conjunturas por ele analisadas. Faz-

\footnotetext{
* Doutora em Sociologia pela Universidade de São Paulo. Professora de Sociologia da Universidade Estadual de Londrina. Centro de Letras e Ciências Humanas, Departamento de Ciências Sociais.

Rodovia Celso Garcia. Cep: 86051-990 - Londrina, PR Brasil.mjderezende@gmail.com
}

se necessário, então, circunscrever esta discussão a um período mais curto. Neste artigo, será apresentada a incursão de Faoro na segunda metade da década de $1990 .{ }^{1}$ Assim, procurar-se-á compreender, particularmente, por que, para Faoro, nos últimos anos do século XX, permaneciam vigorosos os procedimentos oligárquicos no país. Verificar-se-á, também, de que modo seus debates sobre esse período avivavam as suas teses sobre a persistência de procedimentos assentados numa forma de patrimonialismo estamental.É uma pesquisa documental que procura verificar como um dos principais intelectuais brasileiros do final do século XX registrou o processamento da vida política nacional entre 1995 e 1998.

Parte-se do pressuposto de que os artigos de Faoro das décadas de 1970, 1980 e 1990 apontam para a reafirmação da tese central contida em $O s$ donos do poder (1989). Ou seja, a de que se institucionalizou, no país, um padrão de domínio denominado de patrimonialismo estatal, que tem

${ }^{1}$ Alguns outros artigos, de minha autoria, tratam de diversas outras conjunturas analisadas por Faoro. Ver: Rezende (2009, 2009a, 2009b). 
tido, ao longo da história da República, um papel essencial na circunscrição das mudanças a uma lógica que dificulta o desmantelamento da exclusão política. Gabriel Cohn afirma que Faoro pretendeu:

\begin{abstract}
... mostrar como se dá concretamente a politização do aparato administrativo em uma sociedade como a brasileira: como se constitui isto que [...] denominou 'estamento burocrático'. Burocrático porque monopoliza as técnicas da administração da coisa pública, estamento, porque consiste em grupo social particular, com suas regras próprias de recrutamento, seus dispositivos específicos de exclusão, sua peculiar concepção de mundo. Nessas circunstâncias, assinala Faoro, o exercício cru do poder se combina com o particularismo de uma camada social, com o consequente enrijecimento do Estado e a asfixia da sociedade (Cohn, 1988, p.4).
\end{abstract}

No patrimonialismo estatal, o grupo que se encontra à frente dos diversos órgãos do Estado estabelece formas de alianças que resultam em controles e pressões sobre as diversas forças sociais. Ao longo da história do país, essa forma de domínio foi sendo mantida mediante procedimentos, propósitos, ações e concessões que alimentaram e continuam alimentando os interesses de alguns segmentos políticos e econômicos. Conforme afirmava Faoro numa entrevista, em 1995, "No patrimonialismo tudo depende doEstado. A economia é uma concessão, é uma vantagem que você dá para alguém. Eu posso dar para outro. [...] [Isso] supõe um grupo político permanente para manipular essas coisas" (Faoro, 1995 apud Dias, 2008, p.217).

Raymundo Faoro rechaçava a ideia de que os setores que dirigiam o Estado agiam somente para favorecer os setores economicamente dominantes (Faoro, 1976, 1978, 1978a, 2000). Havia, segundo ele, uma articulação de interesses, na qual os segmentos dirigentes e muitos outros que exerciam funções no âmbito do Estado (funcionários, administradores, assessores, técnicos, entre outros) têm também seus interesses contemplados. Por isso, no patrimonialismo, cristalizam-se privilégios, acordos, balcões de negociações nos quais é recorrente a corrupção material e política, uma vez que ocorrem "reiteradas quebras da honestidade administrativa." (Faoro, 1991, p.33). Tais procedimen- tos mantêm o Estado brasileiro numa condição

... retardatária, obsoleta, arcaica. Seria desejável que o empresário fosse independente ou, pelo menos, desfrutasse de alguma autonomia perante o Estado. Pois, enquanto a burguesia não se emancipar, enquanto não ocorrer aqui uma transição capitalista, o país permanecerá arcaico. A modernização será sempre uma concessão, uma forma de ajustamento - e nada mais (Faoro, 1976, p. 4).

Desde a década de 1950, na sua primeira obra intitulada Os donos do poder, até a década de 1990, ele buscava demonstrar - por meio de análises dos procedimentos de governantes e de outros grupos que comandavam o Estado, e também das ações dos segmentos que compunham os setores economicamente dominantes - que havia uma contínua e ininterrupta associação entre a estrutura de classes e o estamento patrimonial, composto por políticos, funcionários do Estado, gerenciadores públicos, assessores, governantes, técnicos, ministros, etc. O elemento central dessa lógica patrimonialista é o perpétuo favorecimento de alguns interesses em detrimento dos interesses coletivos. Num capítulo de Os donos do poder, intitulado A viagem é redonda: do patrimonialismo ao estamento, Faoro mostrava como, em cada conjuntura, iam se renovando e se mantendo, ao mesmo tempo, formas de agir e de proceder sustentadoras de um sistema de poder voltado, sempre, para a perpetuação da exclusão política da grande maioria. Isso não significava, no entanto, que não havia embates entre as diversas forças sociais para ampliar o espaço de fortalecimento de outras práticas políticas mais voltadas para os interesses públicos.

No livro Assembleia Constituinte: a legitimidade recuperada (1981) e nos artigos Uma conta extravagante (1987), O poder do segredo (1980), Faoro demonstrava de que modo, ao longo da história, teria havido muitos embates entre as forças sociais para construir espaços que fossem capazes de servir de ponte para a efetivação da cidadania. Otolhimento e a frenagem foram processos desfechados constantemente pelo padrão de domínio que lutava para que a "ação dos indivíduos [tivesse] uma esfera de ação prévia e fixamente demarcada.”(Faoro, 1991a, p. 27). 
O traço mais forte do patrimonialismo estatal é a reprodução contínua da expectativa dos segmentos dirigentes e dominantes de que todas as tentativas de ampliação da participação política sejam tolhidas e controladas. Em alguns momentos, como após o golpe militar de 1964, houve o recrudescimento das ações para extirpar qualquer liberdade de organização, de expressão, de pensamento e de manifestação. Assim, o estamento dirigente formado, naquele momento, "pela estrutura militar e pela estrutura capitalista vinculada ao Estado, representada pela tecnoburocracia" (Faoro, 1976, p.4) empenhava-se em manter, por um lado, a sociedade civil imobilizada e, por outro, um capitalismo politicamente orientado pelo Estado. Baseado em Max Weber (1999), Faoro distingue o capitalismo economicamente orientado pelo mercado do capitalismo politicamente orientado pelo Estado. Esse último teria vigorado no Brasil desde a colonização e teria moldado uma estrutura social, econômica e política que fortaleceu o enlaçamento do estamento patrimonial com a estrutura de classes.

Sempre, no curso dos anos sem conta, o patrimonialismo estatal, incentivando o setor especulativo da economia e predominantemente voltado ao lucro como jogo e aventura, ou, na outra face, interessado no desenvolvimento econômico sob o [seu] comando político, [procurava] satisfazer [os interesses] imperativos ditados pelo quadro administrativo, com seu componente civil e militar (Faoro, 1989, p. 733).

O período que se inicia em 1964 foi, segundo ele, muito fértil na produção das condições para que a estrutura de classes e a estrutura estamental operassem de modo a deixar ainda mais visível, ao menos para os estudiosos, que a economia do país, à medida que aprofundava o seu caráter dependente, impedia inteiramente a formação de grupos econômicos renovados e capazes de questionar a lógica patrimonialista em curso. Ele dizia: "A história, assim fossilizada, é um cemitério de projetos, de ilusões e de espectros.” (Faoro, 1994, p.112).

Com base nas orientações de Raymundo Faoro, deve-se perguntar: Quais são os estratos sociais que participam, nesse sistema de poder estamental e patrimonialista, do comando político, após o fim da ditadura militar no país? As articulações políticas entre os dirigentes à frente do Estado e a estrutura de classe continuam moldando a forma de mando e de decisão. Foi assim durante o governo que se instaurou em 1985 e também naquele que se instaurou em 1989 (1988, 1991a). Referindo-se à nova Carta Constitucional, ele dizia:

Nas suas linhas próximas, com os acontecimentos recentes, [a Carta] reflete uma luta inconclusa. Espelha, numa vertente, uma batalha perdida, a da soberania popular, a qual esteve nas ruas, nos dias de 1984, com a campanha das diretas, mas não chegou às instituições. Na outra vertente, a vertente vencedora, prevalece um pacto social, originário do país arcaico, expresso no 'capitalismo politicamente orientado', o capitalismo dos subsídios, das concessões, dos favores, das empreitadas, com as suas naturais sequelas, a corrupção, o clientelismo, às alianças interestatais com os burocratas, aqui incluídos os militares, em todas as suas modalidades estamentais. Esta corrente conquistou o leme dirigente, sem que, com seu poder, convença ao vencer. Apedrejada quando mostra a figura, com mil formas, ela escreve a lei, e, na lei, a lei maior. [...] Não seria infundada a suspeita de que tais forças dirigentes não são dominantes. Elas não conquistam o povo, não conseguem a maioria eleitoral, não arrancam aplausos, todavia mandam, fazem e acontecem, antes com mão de ferro, agora maciamente, com pata aveludada (Faoro, 1988, p.33)

O autoritarismo do Estado e o desprezo para com a sociedade civil eram evidentes também em muitos momentos, no início da década de 1990. Esse descaso ficou evidenciado quando os aposentados fizeram um movimento para exigir reajustes nos seus ganhos e o governo não reconheceu seus direitos, mesmo depois de decisão judicial. A dificuldade de efetivação de direitos dava já, naquele momento, indicações de quão difícil seria a implementação, de fato, de um Estado de direito democrático no país (Faoro, 1992, 1992a, 1992b, 1992c, 1992d, 1992e, 1992f).

Não se deve supor, no entanto, que Faoro não reconhecia, em razão da persistência do patrimonialismo estatal, qualquer avanço no que diz respeito ao desenvolvimento de uma sociedade mais democrática. Segundo ele, havia, sim, impulsos nesse sentido, os quais eram dados pela 
sociedade civil organizada. Mas existiam também muitos contraimpulsos visíveis nas ações do Executivo, do Legislativo e do Judiciário. Para ele, esses três poderes eram fontes de muitos emperramentos democráticos (Faoro, 1992a, 1992b). E por que isso se dava? Porque os três poderes agiam de modo estamental, ou seja, visando a atender interesses de grupos específicos, e não da sociedade como um todo. A prática do Poder Executivo era estamental, no início da década de 1990, porque operava de modo a tentar imobilizar os partidos, as elites, a sociedade civil, as classes e os demais poderes. O governo insistia em governar para um determinado grupo específico, procurando, sempre, anular toda e qualquer demanda que se colocasse na arena política. O governo Collor (1989-1992) foi farto de acontecimentos que reafirmam isso.

Na segunda metade da década de 1990, Raymundo Faoro deu continuidade ao exercício de análise da vida política brasileira, tal como havia feito nas décadas de 1970 e 1980. Durante quase 30 anos, ele publicou dezenas de artigos que analisavam os principais acontecimentos indicadores das dificuldades de efetivação de mudanças políticas substantivas no país. No decorrer da década de 1990, ele se dedicou a analisar o processo de democratização em curso, a partir da eleição direta para a presidência da República em 1989. Ele refletiu, especialmente, sobre os governos de Collor de Mello (1990-1992), ${ }^{2}$ de Itamar Franco (1992-1994) e de Fernando Henrique Cardoso (1995-2002). Neste artigo, serão analisados, particularmente, os escritos de Faoro referentes ao período de 1995 a 1998. Objetiva-se trazer à tona os seus argumentos acerca da persistência e da robustez, no final do século XX, do patrimonialismo estamental no país.

Será demonstrado que as reflexões de Faoro buscavam responder à seguinte questão: de que maneira a prática política dos setores com poder de mando e decisão, ${ }^{3}$ na segunda metade da década de 1990, mantinha e reproduzia tanto o padrão de

2 Sobre suas análises acerca do Governo Collor de Melo, ver Rezende (2006, 2006a, 2006b)

3 Tais setores são formados pelos estamentos políticos e burocráticos que comandam a administração dos recur- domínio oligárquico e patrimonialista quanto o de organização social excludente? As análises do autor cobriram diversos aspectos da vida política nacional, buscando demonstrar como os impedimentos e os emperramentos da democracia eram, muitas vezes, anuviados por ações dos segmentos dirigentes, produtores de inúmeros artifícios criados para acobertar a manutenção de atitudes e de procedimentos que dificultavam a formação da condição cidadã. Segundo Faoro, no final da década de 1990, os governantes ainda continuavam a governar para o grupo no poder, o qual perenizava a exclusão social e política da maioria. Como havia ocorrido em outros momentos históricos, "os detentores do poder governam para os detentores do poder, excluindo" (Faoro, 1991a, p.27) todos os demais segmentos que não orbitavam em torno dos interesses daqueles que gravitavam ao redor dos estratos sociais possuidores de poder de mando e de decisão.

Os processos de exclusão de amplos segmentos sociais são analisados por Faoro em seus diversos artigos e entrevistas publicados entre 1995 e 1998 na revista Carta Capital. Neles, Faoro reiterava muitas de suas posições já expressas em obras anteriores $\left(1981,1988,1989^{4}, 1994\right)$, ou seja, a de que as práticas econômicas e políticas expressavam uma forma particular de associação entre o estamento patrimonial e a estrutura de classes. Como dizia Faoro: “[essa associação] influencia o estamento e (ao mesmo tempo) dele recebe o influxo configurador, no campo político.” (Faoro, 1989, p. 203).

\section{O PAÍS ENTRE A PROMESSA DE DEMOCRA- TIZAÇÃO EA AVIDEZ DAS OLIGARQUIAS}

A segunda metade da década de 1990 foi plena de acontecimentos que coroavam o proces-

sos do Estado e pelos segmentos da classe economicamente dominante, que tem seus interesses contemplados dentro dessa lógica do capitalismo politicamente orientado. Como afirmava Faoro (1992g, p.19), trata-se daqueles empresários "que vivem à sombra do Estado, em divórcio da sociedade”, e sempre dispostos a tudo para serem contemplados com polpudos benefícios.

${ }^{4}$ A obra Os donos do poder foi publicada pela primeira vez em 1958. A segunda edição é de 1975. Nela ocorreram mudanças substanciais tanto de forma quanto de conteúdo. A primeira edição teve 271 páginas, a segunda, 766. 
so de transição iniciado na segunda metade da década de 1970, o qual levou a uma normalização política que não efetivava plenamente, segundo Faoro, a condição cidadã. Isso porque, mesmo após a nova Carta Constitucional,

A cúpula de poder, a visível e a, em certas temporadas, invisível, continuou intocada. [...] Continua vigente num Estado menos patrimonial, apenas quantitativamente ferido, o velho estamento, que protege, abona e garante o sistema constituído. Tivemos uma constituição dirigida, não uma constituição dirigente, capaz de institucionalizar a vontade da maioria, a maioria frustrada que esteve na campanha abolicionista, que falou em 1961, com voz no movimento das diferenças, em 84. Isto não quer dizer que se perdeu tempo, que a jornada foi inútil, que não valeu a pena o combate. O que se quer dizer é que, ao contrário do que dirão muitos políticos, é que a obra não está completa. Esta não é a festa da cumeeira, mas a festa - festa sim, porque alguma coisa se fez - da pedra fundamental (Faoro, 1988a, p.25).

As últimas linhas dessa última fala de Faoro indicam que ele não desconsiderava os avanços dos direitos e das conquistas formamente reconhecidos na Constituição de 1988; ele alertava, mediante uma análise minuciosa do período pós-promulgação, que a efetivação dos direitos constantes na nova Carta passava pelo desbloqueio da ação política daqueles interessados em fazer valer, de fato, os seus direitos. A condição cidadã somente seria alcançada se houvesse um processo de luta dos setores subalternos ${ }^{5}$ para que as promessas constitucionais fossem, paulatinamente, implantadas. Há um artigo de Faoro intitulado A lei de São Nunca (1988b, p.35), onde ele levantava vários questionamentos sobre a real possibilidade de as leis ordinárias e complementares serem mesmo implementadas. Isso se devia ao fato de que muitos setores (dirigentes e dominantes), ao longo das décadas vindouras, tentariam impedir que as conquistas sociais presentes na nova Carta, de fato, vigorassem. Por isso, ele afirmava que a condição cidadã não era dada pela formalização da lei, mas sim pela sua efetiva aplicação.

A democracia continuava sendo, na década

\footnotetext{
${ }^{5}$ Termo utilizado por Faoro (1988a, p.25).
}

de 1990, para Faoro, uma promessa irrealizável, não só porque as urnas permaneciam cativas de promessas megalomaníacas (como as de Collor de Mello), mas também porque a vida política nacional continuava dependendo dos supostos sucessos retumbantes de planos econômicos mantenedores de um capitalismo politicamente orientado, ${ }^{6}$ que alimentava todas as formas de corrupção imagináveis, entre as quais estão as fraudes em licitações, os favorecimentos em troca de favores e de verbas para campanhas políticas, a manipulação de informações, as propinas, os presentes, entre outras práticas que colocam o dinheiro público em favor dos interesses de alguns segmentos tanto do setor púbico quanto do setor privado. Apesar da atmosfera democrática, Faoro considerava que ainda prevalecia uma enorme dificuldade, por parte da sociedade civil, de balizar as ações dos que administram e controlam os recursos públicos. Essa dificuldade era o mais nítido indicador de que a democracia se constituía somente numa promessa.

Os procedimentos políticos em vigor, nos primeiros anos da década de 1990, fragilizavam a democracia e a condição cidadã, a exemplo das diversas ações desencadeadas pelo primeiro presidente eleito pelo voto direto, em 1989, após a ditadura militar, Fernando Collor de Melo. ${ }^{7}$ Como exemplo, Faoro citava "a regulamentação legal e administrativa das condições de trabalho [que] entrou no lugar de sindicatos fracos ou inexistentes e dos meios de mediação dos dissídios." (1990, p.19).

Com os salários podados e comprimidos, no início da década de 1990, o poder de ação dos

${ }^{6}$ Expressão, baseada em Max Weber (1999), fartamente utilizada por Raymundo Faoro ao longo de sua obra.

7 Faoro afirmava que eram muitas as medidas de Collor que obstavam a condição cidadã. A sua grande primeira ação, o Plano Collor, era prova disso. Ele dizia: "o chamado plano agride a Constituição, a que mal se redigiu, fresca ainda a tinta. Frauda-a na medida em que instituiu empréstimo compulsório, injuria-a com a apreensão sem o devido processo legal da propriedade, escandaliza-a quando invade e poda salários. O espírito que anima a legislação dos 'pacotaços' é o mesmo do período em que o poder Executivo tudo podia e tudo ousava. A presença do Estado de direito, por enquanto mera retórica (...), não atemorizou, não inibiu, não constrangeu os de sempre” (1990d, p.31). 
trabalhadores estava abalado por uma economia travada pelo Plano Collor I ${ }^{8}$. Isso já demonstrava as dificuldades enfrentadas pelas organizações da sociedade civil, tanto para avançar no fortalecimento de ações contra o imobilismo político, como para construir roteiros de ação capazes de indicar novos rumos para a vida política brasileira. ${ }^{9}$ Segundo Faoro, a fragilização da democracia e da cidadania era evidente, pois

Em épocas democráticas ou de aproximação democrática, os salários não perdem substância, como não a perderam no período de 1943 a 1962, mantendo níveis superiores aos preços, enquanto nos períodos autoritários um grupo primeiro concentra, depois expropria as rendas dos setores que a coligação no poder procura enfraquecer. Ė esta, não a eleição, a substancial diferença entre autocracia e democracia. (1990a, p.21)

Todavia, no decorrer da década de 1990, tanto as medidas econômicas postas em andamento quanto as articulações políticas, assentadas na tese de governabilidade - que justificava todas as ações em nome da necessidade de sustentar as ações do governo e os benefícios de uma situação econômica com inflação controlada e com uma moeda mais forte-criavam inúmeras dificuldades para o processo de democratização em curso. Em nome de tal processo, eram endossadas, dizia Faoro (1993, p.25), ações inteiramente antidemocráticas, com vistas a dar sustentação a procedimentos disparatados e autoritários. Entre esses últimos estavam as ações dos deputados, que visavam a obter ganhos pessoais, as manobras que buscavam controlar o Estado como negócio privado, as práticas para

8 "O Plano provocou mudanças substanciais nas áreas monetárias e financeira, fiscal, de comércio exterior câmbio, de controle de preços e salários” (Moran; Witte, 1993, p.136).

${ }^{9}$ Desde a década de 1980, Faoro vinha chamando a atenção para as dificuldades encontradas pelas novas forças sociais que despontavam na arena política, no que tange ao estabelecimento de objetivos concretos e bem delineados, que visassem à transfiguração da sociedade brasileira. Acerca dos segmentos reunidos em torno do PT (Partido dos Trabalhadores), no início da década de 1980 ele afirmava: “O que não se compreende, em grupos que querem transformar a sociedade e dar conteúdo contemporâneo ao universo político, é a inversão da relação entre o real e as idéias. A proposta por ser abstrata não toca no mundo das realidades, extraviando-se no puro debate intelectual. Com isso, na separação do campo teórico do prático, constrói-se a prática pela teoria, do que resulta a imobilidade da ação.“ (1980, p.7). atrelar ao governo o Congresso, a reprodução, nesse último, de anacronismos políticos, tais como o clientelismo, o mandonismo e o personalismo, a naturalização de representações políticas fabricadas e a fortificação de um processo político onde o parlamento delibera sempre em favor de alguns interesses, e não dos interesses da nação.

Sacrificava-se todo e qualquer princípio democrático em nome de uma suposta forma de evitar o “colapso do país”, o qual poderia se dar por meio das crises institucionais, da volta da inflação, da crise econômica, do aumento do desemprego, do aumento da pobreza, da impossibilidade de dar continuidade aos projetos sociais, etc. Em torno de uma suposta busca de governabilidade, ganhavam proeminência indivíduos "dispostos a todos os oportunismos” (Faoro, 1993, p.25) possíveis. Assim, as práticas oligárquicas, ao contrário do que se supunha, mais se fortaleciam que se enfraqueciam.

O ano de 1993, ano de revisão constitucional, segundo Faoro, foi pródigo em acontecimentos que revelavam as dificuldades do processo de democratização do país. O padrão de domínio oligárquico e antidemocrático se reproduzia de diversas maneiras. Entre elas, Faoro menciona a articulação dos congressistas em torno da obrigatoriedade, contida na Constituição Federal de 1988, de revisão da Carta Magna após 05 anos de sua vigência. De que maneira Faoro analisa as ações reprodutoras do oligarquismo, naquele momento? Ele observa as articulações dos parlamentares com vistas a fortalecer os seus interesses pessoais. Valendo-se de uma zona nebulosa, provocada por inúmeros temores suscitados pela revisão, os políticos, experientes em retirar proveitos próprios, agiam com a desenvoltura de sempre: transformando as incertezas de todos em benefícios privados para alguns.

Assim ele caracterizava o campo das incertezas entre diversos atores, naquele momento:

Os operários temem [a revisão], desconfiados que se toque nos direitos sociais. Os empresários a temem, preocupados com a desmontagem de suas imunidades tributárias e de sua participação na produção da vaca leiteira, ameaçada de socorrer, 
com seu leite, o salário, a vítima constitucionalizada da estagnação econômica. Temem os estados e os municípios, amedrontados de perderem as malempregadas transferências. A própria União a teme, que não dorme com a perspectiva de perder mais do que perdeu na partilha tributária de 1988, que quase a imobilizou. (1993, p.25).

No ano da revisão constitucional, portanto, Faoro conclui que a transição política não só não havia desmontado o oligarquismo e o patrimonialismo, mas também a sociedade civil tinha dificuldades em ser propositiva diante de um problema concreto: que tipo de revisão seria necessário para o país?

Faoro considera que os setores dirigentes, hábeis na arte de capturar para si todas as vantagens, estavam armados para fazer valer os seus planos, ao passo que a sociedade civil parecia perplexa diante da urgência de definir caminhos claros por onde as mudanças deveriam prosseguir. $\mathrm{O}$ resultado foi o seguinte: enquanto não havia clareza do que, de fato, seria revisto, os setores dirigentes davam prosseguimento à sua velha tática: mais importante do que definir o que vai mudar é definir "quem” controlará a mudança.

Pode-se dizer que esse era o nó górdio do processo de construção da democracia no país. Segundo Faoro, continuava presente, na segunda metade da década de 1990, a indisponibilidade de uma parte expressiva dos políticos para enfrentar qualquer imprevisibilidade no que tange às reformas pelas quais o país necessitava passar, para avançar na construção de um Estado de direito democrático e de uma forma de organização social mais justa e inclusiva.

Numa entrevista de 1995, Faoro mostrava que as reformas tributárias, econômicas e da previdência, aventadas pelo governo FHC, que iniciava seu mandato naquele momento, assentavamse numa linguagem incompreensível, o que, para ele, poderia ser interpretado como uma maneira de evitar interferências de alguns segmentos afetados por elas, no processo de sua efetivação. Segundo este autor, isso se inscrevia numa indisposição do governo para o debate e para a interferência da sociedade civil no curso das supostas mudanças que seriam levadas a cabo pelos dirigentes.
Portanto, ressaltava ele que nem mesmo as promessas de mudança davam indicações de se ampliarem os espaços de embates e de enfrentamentos em relação àquilo que deveria ser mudado

Ele diz que uma parte da sociedade, 70\% aproximadamente, não sabia o que significavam tais reformas, e os demais (30\%), que sabiam, não entendiam o que o governo estava propondo. As confusões eram armadas de diversas maneiras pelos dirigentes. Veja-se o caso da proposta de reforma constitucional, em 1995, em que apareciam propostas heréticas de vedação do direito adquirido. Para Faoro, era como se, num passe de mágica, fosse possível remover uma cláusula pétrea da Constituição. Aventar-se essa possibilidade, para Faoro, contribuía para tornar menos compreensível, aos leigos, que reformas da Constituição somente são cabíveis dentro do modo estabelecido pela própria Carta Magna (1995, p.204).

Raymundo Faoro afirmava que o governo Fernando Henrique Cardoso, em 1995, buscava se sustentar e se equilibrar tanto sobre o Plano ${ }^{10}$ Real $^{11}$

${ }^{10}$ Segundo o Dieese (Departamento Intersindical de Estatística e Estudos Socioeconômicos), o "Plano Real [o qual passou a vigorar em $1^{\circ}$ de julho de 1994] passou por mudanças significativas que permitem estabelecer períodos distintos em sua evolução. Nos primeiros dezoito meses, seus resultados foram bastante positivos em várias frentes: ocorreu uma desinflação progressiva, interrompendo-se o processo hiperinflacionário que desestabilizava intensamente a economia; o nível de atividade acelerou-se, ampliando o emprego e reduzindo as taxas de desemprego; a renda apresentou um crescimento que há muito não se via no cenário econômico [...]. No entanto, essa fase de prosperidade foi rapidamente interrompida, após o enfrentamento da primeira crise gerada pela sobrevalorização da moeda nacional" (DIEESE, 1999, p.1). Em 1995, afirma ainda o DIEESE, já se assistia a quedas nos índices de emprego e de produção industrial. Em 1996, ficava evidente que a leve tendência de desconcentração da renda já tinha sido interrompida, o desemprego evoluía mais e mais, ou seja, a cada choque de juros a situação piorava para os trabalhadores. Os choques de juros que visavam a manter a sobrevalorização da moeda não funcionavam mais a partir de 1998. Não só não continham a fuga de capitais, como produziam efeitos destrutivos sobre a renda e o emprego. "O rendimento médio dos ocupados passava a regredir e o desemprego supera os recordes dos últimos quinze anos" (1999, p.1). Diante das dificuldades, o governo recorre ao FMI, tentando evitar "o colapso da política cambial" (p.1), o que não funciona pois, em 1999, o "mercado impôs a adoção da flutuação do real. Na prática isso significou uma maxi-desvalorização, que pôs fim à sua âncora cambial e, do ponto de vista de sua racionalidade, ao próprio Plano Real” (p.1).

${ }^{11}$ Sobre a Lei n.9.069, de 29 de junho de 1995, que estabelecia as regras e as condições do sistema monetário nacional acerca do Real. Ver a íntegra da Lei em www.planalto.gov.br/ccivil/leis/ 19069.htm 
quanto sobre outras possíveis reformas que eram sugeridas naquele momento pelos dirigentes. ${ }^{22}$ Todavia, existiam dificuldades, porque

... ninguém governa na base de um plano monetário e ninguém governa também na base de uma reforma constitucional que virá ou não virá, ou virá $[\ldots]$ de um modo que o governo não quer. Enquanto o governo fala nas reformas tributárias, econômicas, da previdência etc., a oligarquia que domina o Congresso fala em reforma política - o que é uma coisa que, por enquanto, também não se sabe o que é. A única reforma política válida seria trazer a representação do Congresso para os eixos. Dessa ninguém fala. Falo da representação, por exemplo, de Rondônia, em que meia dúzia de eleitores elege um deputado, meia dúzia elege um senador; ao passo que para o Rio de Janeiro e São Paulo são necessários milhares de votos (Faoro, 1995, p.204-205).

No que diz respeito ao Plano Real, Faoro tentava fazer uma reflexão sobre as inúmeras dificuldades que vinham à tona a cada movimento do governo, visando a socorrer o plano, ou seja, evitar que ele implodisse totalmente. Para ele, dentre as medidas tomadas em 1995, com a finalidade de conter a fuga de capital, estavam os cortes de créditos e os choques de juros. As medidas recessivas punham em relevo não só os insucessos do plano, mas também as dificuldades de administrar toda e qualquer mudança pautada em cortes de subsídios, de créditos, etc., em uma economia, como a brasileira, excessivamente orientada pelo Estado. Ou seja, da política partem as orientações básicas para a vida econômica. Isso porque, considera Faoro, nas condições patrimoniais, a economia tem muitos ramos que dependem de vantagens obtidas do Estado. E qualquer vantagem que se dá a alguém e (ou) a algum grupo se dá em troca de outras vantagens, evidentemente (1995, p.217).

Se fosse rastreado o cotidiano das medidas econômicas, na década de 1990, as referentes ao corte de crédito, ao aumento ou diminuição dos subsídios, ou à política de incentivos fiscais, en-

${ }^{12}$ Celso Furtado afirmava que havia sido um erro imenso "manter aquele câmbio na primeira fase do governo Fernando Henrique. Hoje todo mundo reconhece que foi uma grande loucura sobrevalorizar nossa moeda. Tivemos uma grande destruição - ou desnacionalização - do setor industrial, criada pelo próprio governo. “ (2002, p.31). tre outras, detectava-se que havia algo incontestável tanto nos governos anteriores (Sarney, Collor, Itamar) quanto no de FHC: somente os privilegiados de sempre eram beneficiados com tais medidas, dizia Faoro. Essas últimas, continuava o autor, eram sempre justificadas como formas de melhorar a vida do povo de um modo geral, com a geração de empregos e de rendas, o que elevaria, assim, o nível de vida da nação como um todo. Todavia, dizia Faoro, ao longo da história do país, e também nos últimos anos do século XX, isso tudo não passava de falácias. Isso porque o povo nunca foi, de fato, beneficiado por essas medidas, na maioria das vezes feitas em seu nome. E o mais grave é que se formava uma nebulosidade que escondia, de modo cauteloso, quem era realmente beneficiado com tais procedimentos.

Neste país nunca se inquiriu a fundo, em letra
escrita, quem toma de quem. Fala-se sempre
vagamente, das oligarquias, obstinadas e ávidas,
que persistem, ainda que as circunstâncias de-
mocráticas lhes [sejam hostis]. A pergunta é: [que
setores] aproveitaram os incentivos fiscais? Ou
quem se aproveitou desses favores? Já seria tem-
po, apesar das situações constituídas e consoli-
dadas, de fazer essas indagações, dando o nome
aos bois, nem sempre bois metafóricos. Sobretu-
do em tempos em que se fala de reforma fiscal.
Ou será essa também uma reforma impossível,
pela irremovibilidade dos donos dos incentivos,
que sempre são, em última análise, pessoas gra-
das, com vida mansa e em contubérnio com a
política? (Faoro, 1995a, p.60).

Faoro destacava que as principais dificuldades de democratização dos procedimentos em relação aos recursos públicos eram provenientes do modo de atuar dos dirigentes que, numa lógica patrimonialista, agiam como donos da riqueza social, quando cabia a eles distribuí-la do modo mais equitativo possível, e não fazer dela moeda de troca enaltecedora de interesses, muitas vezes escusos. Ou melhor, não eram somente os interesses oligárquicos (próprios dos setores mais arcaicos da economia) que eram contemplados com essas políticas, mas também os segmentos tidos como modernos, ou seja, ligados às atividades mais urbanizadas, e também os setores burocráticos, que administravam e manipulavam os recursos públi- 
cos, colocando-os a favor da manutenção de um dado padrão de organização social e de domínio.

Seguindo uma orientação de Max Weber (1999), de acordo com a qual uma parte dos empresários europeus havia conseguido ascender, independente do poder estatal - e isso teria feito a grande diferença entre um capitalismo economicamente orientado e um capitalismo politicamente orientado $^{13}-$, Faoro afirmava que, para que os incentivos fiscais tivessem a possibilidade de produzir resultados favoráveis ao país como um todo, era necessário que a situação no país mudasse substantivamente, e isso exigia que "a elite empresarial superasse a elite somente apta a captar os benefícios" (Faoro, 1995a, p.60) advindos da má distribuição dos recursos públicos.

Para Faoro, os últimos anos da década de 1990 reafirmavam a persistência de um quadro social e político que ele já detectara em Os donos do poder (1989). Ou seja, não havia sinais de modificação substancial quanto à prevalência de segmentos dominantes e dirigentes voltados somente para a angariação de benefícios estatais que possibilitassem o seu enriquecimento pessoal. E, de acordo com Faoro, no limiar do século XXI, estavam intactos os "cavadores de recursos públicos sempre dourados com caudalosas dívidas oficiais, sempre renováveis e inextinguíveis" (Faoro, 1995a, p.60). Segundo ele, sem remover obstáculos tão profundos da vida social brasileira, dificilmente haveria qualquer ganho substancial para a maioria da nação. E, para ele, o dado que saltava aos olhos, naquele momento, era que o processamento da vida política brasileira injetava alimento na veia desse padrão de domínio, já que as relações de poder reproduziam uma tradição econômica extremamente

13 “... o mercantilismo [...] não constitui o ponto de partida do desenvolvimento capitalista, mas este aconteceu inicialmente, na Inglaterra, paralelamente à política monopolizadora fiscal do mercantilismo, e isto de tal modo que uma camada de empresários, que havia ascendido independentemente do poder estatal, encontrou, após o fracasso da política monopolizadora fiscal dos Stuarts, no século XVIII, o apoio sistemático do Parlamento. Pela última vez enfrentaram-se aqui numa luta o capitalismo irracional e o racional: o capitalismo orientado para oportunidades fiscais e coloniais e para monopólios estatais e o capitalismo orientado para oportunidades de mercado que resultavam, automaticamente, sem medidas impostas de fora, das próprias transações comerciais." (Weber, 1999, p.524-525). dependente do Estado e uma tradição política assentada na administração de benesses e concessões para os de sempre, os quais se ajeitavam a quaisquer governos; bastava observar como isso se processava desde o período ditatorial até o período FHC.

Faoro, no artigo $O$ terremoto como critério de governo (1995b), indagava que a tão propalada reforma administrativa, prometida em meados da década de 1990, não dava indicação de que seria capaz de romper com os vícios políticos sedimentados no aparelhamento estatal. Pelo contrário, segundo ele, do modo como era apresentada, caso fosse implementada, tal reforma daria vazão ao fortalecimento do clientelismo, por exemplo. ${ }^{14}$ Isso não significava, no seu entendimento, que, nas propostas de reforma administrativa, houvesse somente insensatez. Havia alguns pontos sensatos, como o estabelecimento de teto para os salários dos servidores públicos e a "indispensabilidade da lei, em qualquer ramo do Estado" (Faoro, 1995b, p.24). Quando a proposta de reforma sugeria a possibilidade de instaurar a demissibilidade por excesso de quadros - o que significava, na verdade, a quebra da estabilidade -, logo vinha à mente de muitos desavisados que essa era a solução para todos os males que se abatiam sobre o país. Ledo engano, dizia Faoro, já que essa medida era somente uma forma de propiciar carta branca para os políticos dirigentes fazerem o que bem entendessem. Ele asseverava que, em nome do interesse de todos, não havia dúvida de que os políticos lançariam mão do expediente da demissibilidade para não só derrubar os desafetos, mas também para colocar nos quadros públicos os seus protegidos.

Segundo Faoro, essa medida constituía-se, então, em terreno fértil para o fortalecimento do clientelismo e do personalismo no país, visto que cada governante faria e desfaria os quadros do fun-

14 Bolivar Lamounier afirma que é necessário "distinguir dois tipos de clientelismo. Se o primeiro, tradicional, evoca o parentesco e a pequena comunidade, o segundo, eminentemente moderno, tem como horizonte o conjunto do espaço econômico. Se aquele é uma extensão natural de vínculos primários, este [se] baseia em estratégias de ganho e de poder político. Se o clientelismo tradicional declina e definha - e há boas indicações nesse sentido -, o moderno esbanja vigor e juventude.“ (2009, p.24). 
cionalismo. O que seria efetuado sob o manto de uma suposta licitude em que os cargos extintos não poderiam ser, por uma quantidade $x$ ou $y$ de tempo, recriados. Faoro diz que quem conhecia bem os meandros das ações da maioria dos políticos brasileiros não tinha dúvida de que eles não criariam os cargos com aqueles mesmos nomes, mas estabeleceriam várias maneiras de recriá-los com novas designações capazes de burlar qualquer quarentena temporal.

Por isso, ele perguntava: será que os políticos brasileiros mereciam tantos poderes assim? Tanta confiança? Ele afirmava que, de fato, político algum mereceria poderes tão exorbitantes e arbitrários. Muito menos os políticos brasileiros, curtidos nas pelejas oligárquicas, patrimonialistas e clientelistas. Ele perguntava, ainda:

Será que a faculdade sem controle e sem medida não poderia cair nas mãos de um louco ou de um demagogo? O sufrágio popular ainda não descobriu o meio de distinguir entre a loucura e a sanidade dos inventores de catástrofes, para, em nome delas, impor as suas fantasias aos governados. A sede de absolutismo é inerente ao poder, corre nas veias do mais democrático dos governantes, fonte da autocracia e da corrupção. Sempre que há, entre os legisladores, a fraqueza de aumentar o poder do governante, é bom lembrar a advertência Jefferson ${ }^{15}$ : a democracia é o exercício da desconfiança. Que são as eleições e os controles constitucionais senão a desconfiança permanente ou periódica? (1995b, p.24).

Por outro lado, ainda no ano de 1995, o autor destacava que havia outro embate, o da reforma política, que revelava os percalços e, até mesmo, os emperramentos do processo de construção de procedimentos políticos capazes de combater os autoritarismos sedimentados nas instituições brasileiras. Não era por acaso que a "oligarquia que dominava o Congresso” (1995, p.204) passava a falar, naquele momento, em reforma política. Ela parecia disposta a várias ações e mano-

${ }^{15}$ Raymundo Faoro se referia a Tomas Jefferson (17431826), o qual foi o redator da Declaração de Independência dos EUA e também presidente desse país entre 1801 e 1809. Faoro estava se pautando pelas posições de Jefferson, segundo as quais mesmo que a maioria pudesse errar, em suas decisões, era sempre melhor esse erro do que a inação (Jefferson, 1979). bras para vender a impressão de que essa era, agora, a sua bandeira principal. Dentro de uma mesma lógica, já em vigência no país desde 1822, ela tentava levar avante uma proposta de inovação que não chegava a ser sequer uma reforma, pois mantinha intacta uma forma de representação que servia exatamente aos propósitos oligárquicos e perpetuadores da exclusão política, razão pela qual Faoro fazia suas ponderações: “... que inovar não é reformar, sabem os conservadores de todos os tempos (1990b, p.25)

Faoro alertava que todas as propostas de inovação vindas das oligarquias, ao longo da história do país, mantinham intocados os pilares que lhes davam sustentação e possibilitavam a sua fixação no âmbito das instituições. E tais pilares se assentavam justamente no tipo de representação falseada que havia no país. "Há, na Câmara dos Deputados, à custa das densas populações dos Estados mais desenvolvidos, cerca de 20\% dos deputados que só se elegem pelo artifício constitucional e, depois de eleitos, são instrumentos do governo e obedientes à máquina central (1991b, p.19). As propostas de reforma política das oligarquias não tocavam, de modo algum, nesse artifício, uma vez que ele propiciava a manutenção dos acordos e das alianças que sustentavam a prevalência dos interesses pessoais e privados no âmbito institucional, como insistia Faoro.

Tanto nos momentos de alguns consensos entre o Executivo e o Legislativo quanto nos momentos de dissensos, ficam claras, segundo Faoro, as amarras que dificultavam a construção de procedimentos políticos não-autoritários. Ou seja, como aconteceu no primeiro momento do governo FHC e no governo Collor, ora o chefe do Executivo voltase para o Congresso e tenta estabelecer algumas afrontas - baseadas na tese de que ter sido eleito como presidente é razão suficiente para que o Congresso se submeta a ele-, ora o Executivo, em nome da governabilidade, chancela, mediante alianças e acordos, em troca de apoios, todas as práticas negadoras da transparência político-administrativa. Ainda, no entender do autor, as ações do Congresso, perpetuadoras de todos os vícios polí- 
ticos, relacionavam-se também com o fato de que os presidentes da República, mesmo os da década de 1990, pareciam não ter um programa de governo. O que eles pareciam ter eram propostas vagas de algumas reformas que passavam a balizar as suas ações. Todavia, quando eram indagados acerca da natureza social e política de tais propostas de reformas, alguns presidentes tangenciavam a pergunta com ironias e bravatas. Se a relação do Executivo com o Legislativo estava pautada pela viabilização de algumas reformas, como sustentava o governo FHC em 1995, então era necessário esclarecer a natureza profunda de tais reformas. Mas isso, geralmente, não ocorria.

Um repórter pergunta ao presidente se ele é neoliberal, agora, e ele responde, com o maior enfado, que isso não passa de nhenhenhém. Perdeu a oportunidade de dar uma explicação séria, sendo que o repórter propunha uma questão relevante que está no ar: se houve, por parte de Fernando Henrique [Cardoso], uma apostasia ou não, se ele é socialdemocrata ou neoliberal (Faoro, 1995, p.206).

Por que era essa uma questão relevante? Porque, se ela fosse esclarecida, haveria mais elementos para entender a natureza das reformas propostas pelo governo, pois era óbvio que, em 1995, o governo eleito procurava ancorar-se sobre o Plano Real e sobre suas propostas de reformas pouco esclarecidas. Não havia projeto de governo claro, nem mesmo uma diretriz claramente traçada. Isso possibilitava que a oligarquia ${ }^{16}$ que o sustentava crescesse em ações políticas argutas e favorecedoras de seu próprio projeto, ${ }^{17}$ ou seja, o de manter-se, como sempre, no controle das instituições, ${ }^{18}$ conforme assinalava Faoro.

${ }^{16}$ Sobre o papel dos setores oligárquicos no processo de transição política no Brasil, ver Faoro $(1981,1989)$ e Furtado (1992).

${ }^{17}$ Isso foi discutido em Rezende (2008, 2009).

18 "Diversos pensadores sociais constatam que após a república ocorreu uma reorganização das forças oligárquicas em bases cada vez mais complexas e solidifícadas, de modo a parecer cada vez mais difícil o seu combate, a sua derrota. Por isso, Silvio Romero definia-se como comprometido com o dever intelectual de atacar os políticos, os quais eram, essencialmente, os representantes das oligarquias. No texto Nosso maior mal, ele sublinhava a leviandade e o alheamento das elites no que tange à vida nacional. Ele perguntava: no que se transformaram as câmaras municipais e as assembleias estaduais? Ele respondia: "Em ter-

\section{CASUÍMOS,${ }^{19}$ AUTOCRACIA E EXPEDIENTES ANTIDEMOCRÁTICOS: os desafios para as mudanças políticas no Brasil no final da década de 1990}

Nos artigos e entrevistas de meados da década de 1990, Raymundo Faoro alertava que era impossível entender o processo político brasileiro e os seus rumos atuais, sem levar em consideração todos os movimentos, ações e estratégias do PFL (Partido da Frente Liberal). Isso porque o PFL era um agrupamento político de direita, com habilidade de aproximar-se e de aliar-se com os diversos grupos que estivessem em posição de poder. Seus principais líderes haviam condescendido não só com a ditadura militar, já que eram oriundos do partido que havia dado apoio ao regime instaurado em 1964, ou seja, a ARENA (Aliança Renovadora Nacional), ${ }^{20}$ mas também haviam-se aliado ao PSDB (Partido da socialdemocracia brasileira), que se encontrava no poder naquele momento.

Em 1995, Faoro afirmava que não era possível saber claramente, ao menos então, se o PFL iria puxar o governo cada vez mais para a direita. ${ }^{21}$ Talvez sim, talvez não. Havia uma indefinição, até mesmo pela falta de liderança do presidente Fernando Henrique Cardoso, dizia ele. Em entrevista à revista Carta Capital, em 25 de junho de 1997, Faoro afirmava acreditar que, se não fosse a

ríveis ratoeiras para arrancar do povo os últimos vinténs enriquecendo por todo o país verdadeiros clãs locais de mandões insaciáveis. As assembleias estaduais são guardas avançadas ao serviço das oligarquias, cujos interesses defendem com a espoliação, muitas vezes, dos haveres das populações e sempre com o sequestro das liberdades públicas." (Romero, 1910, p.60).

${ }^{19}$ Faoro, em A santidade do casuísmo (1996), afirma: “o casuísmo, velho e inocente galho da teologia, supõe uma regra ética que se amolda aos casos de consciência. Entre a regra e o caso há uma terra minada e subtil, que, tratada com jeito e esperteza, justifica qualquer conduta, pecaminosa ou criminosa." (Faoro, 1996a, p.31).

${ }^{20}$ A Arena mudou a sigla para PDS (Partido Social Democrático) a partir da reforma partidária de 1979, que instaurou no país o pluripartidarismo. Ver: (Rezende, 1996).

${ }^{21}$ Para Faoro, a direita, no Brasil, é composta por aqueles (pessoas e grupos) que conseguem, através de uma intimidade com a estrutura de mando e de decisão, direcionar as ações do Estado para a efetivação de seus interesses. Ela é a seiva do Estado patrimonialista. São segmentos que atuam no interior do aparelhamento estatal em nome próprio, operacionalizando, assim, o padrão de domínio vigente. 
aliança com o PFL, o presidente Fernando Henrique Cardoso poderia ter conduzido outro tipo de política. "Essa aliança era dispensável. Ele poderia ter os votos mantendo incólume sua autoridade. [...] Mas acho que ele jogou esse capital fora.” (1997, p.250).

O PFL congregava, assim o entendia Faoro, um número expressivo de indivíduos com habilidade e agilidade para manejar o patrimonialismo brasileiro. Vinha daí a sua força política e sua relevância para os pactos de poder estabelecidos no período da transição política e da pós-transição. ${ }^{22}$ Se, no patrimonialismo, tudo depende do Estado - o qual faz concessões aos grupos que conseguem, de alguma maneira, disputar as suas benesses -, a existência de um grupo político permanentemente voltado para manipular os interesses daqueles que dependem das concessões é que dá sempre sobrevida, de acordo com Faoro, ao padrão de domínio e às relações de poder oligárquicas, casuísticas e autocráticas. ${ }^{23}$ Dentro de tais condições, o PFL constituía-se num grupo hegemônico que conseguia manipular muito bem o Estado patrimonialista em razão de sua intimidade com o poder, tanto que “quem opera a política neste governo [primeiro mandato de FHC] é o PFL” (Faoro,1996, p.230), atestava o autor de Os donos do poder.

E dizia o autor que, quem opera a política opera de modo autocrático, tanto que as reformas defendidas pelo grupo de poder, do qual fazem parte o PFL e o PSDB, são justificadas como uma forma de abrir "o Brasil para o mundo". As privatizações, por exemplo, cumpririam, essencialmente, esse objetivo, segundo os condutores desse pacto de poder em vigor. Era óbvio, dizia Faoro, que "o povo não tinha vantagem alguma com essas reformas" (1996, p.230) postas em andamento. O PFL, como destacava Faoro, mantinha-se muito atuante na operacionalização das reformas que interessavam sobremaneira a alguns grupos

${ }^{22}$ O período pós-transição é comumente designado como aquele inaugurado após a promulgação da Constituição de 1988.

${ }^{23}$ Faoro argumentava que os empresários (mesmo os maiores, que supostamente seriam mais independentes) não podem "ir muito longe com críticas em um país patrimonialista, porque se forem muito longe levam um tombo.“ (1997, p.246). políticos e econômicos; por isso, “o vice [Marco Maciel, do PFL] tinha cara de presidente. [Num] estilo silencioso, atuante, eficaz, eficiente” (p.230) ele cumpria o seu papel de funcionário competente da oligarquia autocrática. Essa sua performance não era novidade, pois ele havia sido também um funcionário muito eficiente do regime militar. Numa entrevista em 24 de agosto de 1998, Raimundo Rodrigues Pereira perguntava a Celso Furtado se ele considerava sintomático que o vice de Fernando Henrique Cardoso fosse Marco Maciel, "que esta[va] dedicado, dia e noite, aos detalhes de uma ação política clientelista, do tipo mais retrógrado" (Pereira, 1998, p.52). Furtado deu a seguinte resposta:

Ele é isso. Nunca ocultou o que realmente era [...] Marco Maciel é de uma transparência completa. Ele foi um simples funcionário da ditadura, fiel, trabalhou bem, foi recompensado, não atropela ninguém, ele é claro no que faz, não engana ninguém. $\mathrm{O}$ fato de Fernando Henrique o escolher é porque queria o apoio dele. [...] Não o culpo de nada, a culpa é daquele que o escolheu. (1998, p.53).

Muitos políticos tinham sido, ao longo de anos, os mestres dos expedientes casuístas que mantiveram intactas as ações da autocracia contra qualquer possibilidade de emergirem práticas democráticas no país. Agiram assim durante a ditadura militar e continuavam a agir, desse modo, após o seu fim. Faoro afirmava que havia dois momentos exemplares desse processo casuístico e autocrático, o que pode ser assim sintetizado:

A instituição das eleições indiretas para presidente e governadores (com critérios variáveis e flexíveis), depois que a de 1965 sagrou nas urnas, em dois grandes estados, políticos de oposição. Foram os atos institucionais números 2 e 3 (1965 e 1966). Depois, em 1977, criaram-se os senadores biônicos, com o fim de, perdida a eleição, assegurar a maioria no Senado. (Faoro, 1996a, p.31).

Para Faoro, os políticos, que davam apoio à esperteza armada dos militares e dela se aproveitaram com suas manobras cheias de inventividade para afastar qualquer imprevisibilidade do cená- 
rio político, eram perpetradores de práticas casuístas que continuavam presentes no final da década de 1990. Era visível que o país estava "agora, volvidos anos, num tempo circular de uma monótona e repetitiva crônica” (1996a, p.31). Tanto no passado recente (décadas de 1960, 1970 e 1980) quanto no presente (ou seja, nos últimos anos do século $\mathrm{XX}$ ), estavam lá as chamadas manobras casuísticas, assim denominadas porque "a minoria, em nome da maioria nominal e contrafeita, se substituía às eleições ou as temperava, com a conivente prudência dos congressistas efetivamente escolhidos pelo povo.” (p.31)

Em razão de uma história sempre circular, em 1996, em seu entendimento, estavam novamente na ordem do dia as manobras casuísticas. Era interessante observar que muitos indivíduos experientes nesse tipo de prática encontravam-se ativamente na vida política nacional naquele momento; aliás, formavam eles o bloco de sustentação do governo do PSDB. Inscrito na complacência, "o casuísmo existe quando uma regra, uma lei é aplicada ao caso, acomodando-se às circunstâncias ou à malícia. [...] O casuísmo, a arte de tornar relativos os princípios, degradou-se ao ponto de fazer todos os princípios relativos.” (Faoro, 1996a, p.31).

Raymundo Faoro, em A santidade do Casuísmo (1996a), argumentava que a proposta de reeleição, ${ }^{24}$ do presidente da República, que tomava forma naquele momento, era uma manobra casuística. "Se a reforma constitucional ajuda, melhora e favorece o seu promotor, certamente há casuísmo. Trata-se, na verdade, de acomodar, modificando-a, uma regra constitucional a um interesse pessoal" (p.31). Não havia como derrotar, extinguir, esse tipo de prática, enquanto fossem predominantes, na vida política brasileira, formas de esperteza justificadoras de todas as condutas que visavam a alargar as vantagens políticas de al-

${ }^{24} \mathrm{O}$ Congresso aprovou a emenda constitucional $\mathrm{n}^{\mathrm{O}} 16$, de 04 de junho de 1997, instituindo que o presidente da República, os governadores de estado e do distrito federal e os prefeitos poderiam "ser reeleitos para um único período subsequente". Veja a íntegra da Emenda em: www.dji.com.br/constituição_federal/ec016.htm. Acesso em: 15 maio 2009. guns grupos em detrimento da nação. ${ }^{25}$ A reeleição, sem dúvida, propiciava um aumento dos gastos públicos canalizados somente em favor de alguns interesses, e não do país como um todo. ${ }^{26}$

Faoro considerava que os casuísmos não eram, muitas vezes, visíveis com facilidade, já que eles se escondiam nas dobras de uma multiplicidade de ações políticas. Não somente os governistas operavam com manobras casuísticas ao defender a emenda da reeleição, mas também o faziam aqueles que defendiam que a emenda não deveria ser imediatamente aplicada. Isso era uma demonstração de que a oposição desejava a reeleição a partir do próximo mandatário. Provavelmente, havia aí a suposição de que algum membro da oposição se tornasse o próximo presidente da República. Ao agir desse modo, de acordo com ele, era evidente que também a oposição era dada a práticas casuísticas. Raymundo Faoro, em 1996, projetava que, provavelmente, nos anos posteriores, sendo ou não a oposição ao governo FHC vencedora, o país continuaria preso "num tempo circular de uma monótona e repetitiva crônica" (p.31). Ele fazia as seguintes indagações:

E os que impugnam a proposta estão com o coração puro e as mãos castas? Não quer o maior e mais luzido opositor da reforma, confiante no futuro e na recuperação política, que ela se faça, mas somente para o próximo presidente - isto é, ao seu juízo e no juízo de seus partidários -, ele próprio? Não haverá, contra um casuísmo, outro casuísmo? [...] O que há de intrinsecamente mau na troca de ardilezas não são os métodos astutos, mas o que deles resulta que é a ilegitimidade do mandato angariado com fascínios artificiosos para dizer o mínimo. (1996a, p.31).

Faoro afirmava que uma prova de que alguns políticos desejavam, de fato, combater o casuísmo poderia ser dada se eles defendessem a reeleição para 2006, quando o atual e o próximo

${ }^{25}$ Há alguns artigos que discutem os efeitos de mudanças institucionais, como a Emenda da Reeleição, sobre as diversas esferas da vida social. Bender \& Nakaguma afirmam, por exemplo, que "a Emenda da Reeleição, ao criar a possibilidade de o governante permanecer no cargo por mais de um mandato, internalizou os benefícios e os custos (Meneguin; Bugarin, 2001) da manipulação eleitoral das políticas públicas.“ (Bender; Nakaguma, 2004, p.3).

${ }^{26}$ Sobre o aumento dos gastos públicos propiciados pela emenda da reeleição, ver: Meneguin e Bugarin (2001) 
pretendente ao cargo de presidente da República já teriam cumprido os seus respectivos mandatos. Somente dessa maneira haveria certeza de que os interesses pessoais não estariam sendo postos em primeiro plano. Todavia, para Faoro, isso não seria feito de modo algum, muito pelo contrário, invocavam-se mais e mais as razões mais estapafúrdias para justificar a Emenda da Reeleição nos termos que beneficiassem, de imediato, o governante em exercício. Justificava-se, até mesmo, que já se ouvia uma voz rouca das ruas a exigir a aprovação da referida emenda constitucional. Faoro ironizava dizendo:

Mas, para a glória da República, uma orelha vigilante percebeu, captou e transformou em realidade os sons inarticulados da pobre e desvalida gente. Que não se diga que o intérprete estava interessado, para benefício próprio, na mensagem inaudível. O povo a queria, feliz com o frango e o iogurte nosso de cada dia, dádivas do atua governo e do abençoado plano real. De posse dessa verdade inabalável, passou o governante milagreiro - ou taumaturgo - à ação: convocou os estados gerais - nobreza, clero e povo - para a grande e salvadora empresa. (1997, p.31).

Faoro constatava que muitas manobras se sucediam uma após outra, nessa empreitada de justificar a aprovação da Emenda da Reeleição. E saltava aos olhos a tentativa de fazer parecer que não havia manobras casuísticas; tudo era mostrado como o mais puro desejo do eleitor. Faoro dizia que nem tudo era repetição nos caminhos circulares que o país percorria. Havia algumas repetições e outras novidades. Entre aquelas primeiras estava, no decorrer da República, a supremacia do presidente da República sobre o Congresso. Entre aquelas segundas, era possível observar, na última década, algo indicador de uma mudança digna de nota: a constante invocação do povo, melhor dizendo, do eleitor, como forma de justificar as ações que nada traziam de benefícios reais para a maioria da população. Isso era novo, pois as diversas combinações políticas na República velha, por exemplo, não se davam ao trabalho de "invocar ou convocar o povo" (Faoro, 1997, p. 31).

Todavia as coisas mudaram um pouco no país, nos últimos tempos, afirmava Faoro. "De uns tempos para cá, os políticos descobriram o eleitor - o eleitor, nem sempre o cidadão - e o associaram aos seus planos, se não em carne e osso, ao menos nas aparições pagas nos meios de comunicação" (1997, p. 31). Observe-se que o eleitor continuava desprovido de cidadania, tal como ocorreu ao longo da história, mas agora, no final da década de 1990, visualizava-se, por parte do chefe do governo federal, até mesmo, uma tentativa de difundir que havia um diálogo entre ele e o povo. O presidente da República acreditava, então, que dialogava "sem intermediários, com os fantasmas que criou” (p. 31).

Havia uma combinação entre manobras autocráticas e alucinações (vejam-se, por exemplo, as vozes de um povo-fantasma, que passavam a ser ouvidas pelo presidente FHC) e entre cinismos e deslizes éticos ${ }^{27}$ que culminaram no milagre da multiplicação dos votos para aprovação da Emenda Constitucional da reeleição ${ }^{28}$ (Faoro, 1997a, p. 238). Na entrevista intitulada $A$ apostasia de Fernando Henrique, de 24 de junho de 1998, publicada em Carta Capital, Faoro afirmava que o presidente da República havia-se convertido inteiramente ao oligarquismo, e todas as suas ações mostravam, durante o primeiro mandato, que FHC estava fazendo uma travessia ${ }^{29}$ da esquerda para a direita.$^{30} \mathrm{Em}$ 1998, era possível dizer que ele era, de fato, um converso.

27 "Houve várias denúncias de que o governo teria comprado votos para aprovar a emenda da reeleição, em 1997 O jornal Folha de S. Paulo publicou reportagem na qual transcrevia gravações em que o deputado Ronivon Santiago (PFL-AC) afirma que recebeu R\$ 100 mil inicialmente e outros $\mathrm{R} \$ 100 \mathrm{mil}$ seriam pagos por uma empreiteira. O governo FHC sufocou a criação de uma CPI para apurar as denúncias" (Dias, 2008, p.242).

28 "A reeleição foi mais do que um erro. Foi um absurdo. Creio que, se Fernando Henrique tem consciência das coisas, e acho que ele tem, está absolutamente arrependido. A reeleição foi uma violência conseguida por todos os meios, inclusive meios não apurados e que deviam ser apurados. Houve denúncias de tráfico de dinheiro. “ (Faoro, 2001, p.10).

${ }^{29}$ A travessia indicava um movimento de deslocamento do centro para a direita. "O centro é que faz [a] intermediação entre setores utópicos e setores anacrônicos" (Faoro, 1991, p.166). Deslocar-se do centro para a direita significava aproximar-se dos segmentos defensores de práticas políticas marcadas pelo anacronismo.

${ }^{30}$ A direita, para Faoro. é aquela que se alimenta da tutela do Estado e de todos os tipos de manobras estamentais para manipular, em vista de interesses próprios, as posições de poder. E, no Brasil, ela não parece minimamente disposta a se renovar; por isso, ela ordena a vida política e institucional, reafirmando constantemente aquelas ações mais retrógradas e capazes de consolidar e promover privilégios. Sobre isso, ver: Faoro, 1990c. 
Sua conversão à direita oligárquica podia ser mais bem observada na sua maneira de invocar a tese do caos para assustar eleitoralmente a população brasileira. A opção era: FHC ou o caos e a baderna. É claro, dizia Faoro, que Cardoso estava supondo que essa sua postura não traria danos para a ordem democrática, já que era somente uma forma de assustar os eleitores. Todavia, conforme ele, esse tipo de fala, vinda de um presidente da nação, poderia ter

...consequências fatais para a ordem democrática. O presidente não está levando em consideração o conceito básico da democracia, que é a soberania popular, o sufrágio eleitoral. É curioso que um cidadão com o currículo de Fernando Henrique em quatro anos de poder se tenha convertido num político capaz de dizer isso. É, talvez, o caso mais singular da história política do Brasil: a mudança de uma pessoa que entra na oligarquia e se torna mais oligárquica que os oligárquicos nordestinos (Faoro, 1998, p. 254).

Observe-se que Faoro afirmava, em 1998, que se a divulgação da ideia "FHC ou o caos" ganhasse grande vulto, poderia haver consequências inimagináveis, visto que continuava havendo, no país, riscos de conspiração, até mesmo, a militar. Para ele, alguns militares ainda supunham que, diante da possibilidade do caos, eles deveriam agir. Esse tipo de entendimento não estava completamente morto na década de 1990. Existiam, ainda, outros riscos trazidos pelo aprofundamento da ideia de tragédia social, aventada pelas lideranças mais conservadoras: a de um golpe civil. Assistiase a uma ameaça de que, se o eleito para presidente da nação, nas eleições de 1998, não fosse aquele que já estava no cargo, poderia haver uma conspiração política no Congresso contra o novo presidente da República consagrado pelas urnas. A existência de um boicote para solapar as condições de governabilidade era uma espécie de golpe civil (Faoro, 1998).

A aliança PSDB/PFL tinha revelado alguns traços importantes da vida política nacional, de acordo com o autor. Um deles era a persistência de um argumento que esteve sempre na boca dos segmentos interessados em manter incólume a práti- ca autoritária, ou seja, a ameaça constante de que a vitória de qualquer outro candidato na eleição presidencial, que se aproximava, mergulharia o país numa verdadeira tragédia social, a qual traria, no seu bojo, a volta da inflação e o abandono de todas as políticas postas em andamento até então (1998).

Não somente Cardoso, no seu entender, insistia nisso, mas também outros políticos, como Antônio Carlos Magalhães. Faoro afirmava que considerava intrigante o fato de o primeiro ter transformado em slogan de campanha uma fala acerca do caos social, que tinha semelhança com aquelas posturas que haviam, no passado, defendido golpes autoritários, tal como o golpe militar. Que Antônio Carlos Magalhães, líder do PFL, invocasse tal idéia não causava espanto, pois sua história política, conforme Faoro, mostrava que um golpe a mais ou um a menos não faria diferença, já que ele havia sido um dos suportes do regime que foi instalado em 1964, por exemplo. Todavia, era muito preocupante, de acordo com ele, que alguém que havia assumido um compromisso democrático, tal como FHC, enveredasse por esse caminho que reiterava o autoritarismo (Faoro, 1998).

Quando o repórter perguntava a Raymundo Faoro se ele havia se surpreendido com as atitudes de Cardoso, ele dava a seguinte resposta:

Me surpreendeu, muito. Primeiro, Fernando Henrique me surpreendeu na aliança que fez para chegar ao governo, que era desnecessária. $\mathrm{O}$ argumento usado no tempo é que essa aliança teria de ser feita, de qualquer maneira, no Congresso. Mas há uma grande diferença qualitativa em uma aliança feita para se eleger e uma aliança feita para governar. Quer dizer, uma, a para eleger, é transitória, destina-se a um certo objetivo instantâneo; a para governar é definitiva. Nesta, a pessoa vende a alma ao demônio. (1998, p.256).

\section{CONSIDERAÇÕES FINAIS}

Ao longo de diversos artigos e entrevistas, publicadas na segunda metade da década de 1990, Faoro dá destaque às surpresas advindas tanto das alianças políticas feitas para ganhar a eleição e para governar quanto da conversão, quase total, dos 
dirigentes, ao oligarquismo. ${ }^{31}$ Mas ele mostra também quão surpreendente era o modo de Cardoso se apresentar como o mestre de uma turba ignara. Ao denominar os seus críticos de ignorantes e "neobobos", ${ }^{32}$ ele passava a ideia de que era "o reitor moral da sociedade” (Faoro, 1998, p. 257).

Mas, seria o povo uma massa ignara, incapaz politicamente de entender os rumos da política brasileira, naquele momento? Faoro afirmava que, se fosse feita uma análise, numa perspectiva histórica, detectava-se que tinha havido mudanças na população brasileira, no que diz respeito à sensibilidade política. No entanto, essa ideia de que o presidente da nação deveria colocar-se como o "reitor moral da sociedade" revelava uma percepção muito comum entre os políticos brasileiros: a de que o povo era incapaz politicamente. Fazendo uma reflexão sobre o período pós-1950, Faoro dizia que, não obstante ter havido uma ditadura que se empenhou cotidianamente para tirar “da população a consciência política” (1998, p. 263), o que levou, até mesmo, à eleição de Collor, em 1989, não existia dúvida de que a população estava readquirindo, na década de 1990, uma sensibilidade política maior e mais aguda. Todavia, diante disso, as oligarquias tradicionais e as novas, ou seja, aquelas que tinham se constituído em razão da conversão mais recente de alguns grupos ao modo de agir oligárquico, indicavam que

궛 “o sufrágio popular [que é] capaz de eleger alguém que o grupo” no poder não aceita (p. 266), deve ser rechaçado inteiramente.

Esses elementos, analisados por Faoro, revelavam muito mais da vida política brasileira do que se imaginava. As reações aparentemente atabalhoadas traziam à tona o quanto os setores dirigentes continuavam empenhados em manter o autoritarismo intacto. E por que a base governista, mestra na arte

${ }^{31}$ No início de seu governo, Fernando Henrique Cardoso "realmente se esforçou para se apresentar como de centro esquerda, a fim de assumir o papel de condutor da aliança governista. Ele, hoje, perdeu este papel e aceitou tê-lo perdido." (Faoro, 1998, p. 260-261).

${ }^{32}$ O termo "neobobo" era utilizado para designar os que denominavam as políticas de FHC de neoliberais. Ver o artigo de Faoro intitulado Mais um bando de neobobos (1998a). da intimidade com o poder, considerava inadmissível a sua não-continuidade, após 1998, nas posições de poder que desfrutava? Porque sabia que o segundo governo FHC não poderia dar qualquer guinada que comprometesse os interesses da base que lhe dava sustentação. Cardoso também sabia, segundo Faoro, que qualquer mudança substantiva no modo de governar faria com que a sua base entrasse "em combustão” (1998, p. 267).

Isso demonstrava que a nação já estava vivendo uma espécie de caos que assomava quando os políticos governistas e membros do governo falavam (ou insinuavam) que não havia qualquer outra saída para o país, a não ser reeleger Fernando Henrique Cardoso. "É a antiga tese da República Velha, da beira do abismo. Aqueles políticos nunca perceberam que não estavam à beira do abismo, estavam é dentro do abismo.” (p. 267).

(Recebido para publicação em agosto de 2009) (Aceito em fevereiro de 2011)

\section{REFERÊNCIAS}

BENDER, S.; NAKAGUMA, M. Y. A Emenda da Reeleição e a Lei de Responsabilidade fiscal: impactos sobre ciclos e performance fiscal dos estados (1986-2002), 2004. Disponível em: www.anpec.org.br/encontro2004/artigos/ A04A025.pdf Acesso em: 15 maio 2009.

COHN, G. Uma persistência de geólogo pelas camadas do poder. O Estado de S. Paulo, 19 nov. 1988, Cad.2, p.4,.

DIAS, Maurício (Org.). Raymundo Faoro: a democracia traída (entrevistas). São Paulo: Globo, 2008.

DIEESE. 5 anos do Plano Real. 1999. Disponível em: www.dieese.org.br/esp/real5ano.xml Acesso em: 12 maio 2009.

FAORO, R. Romance sem herói. Revista Veja, n. 399, p. 3-6, 28 abr. 1976. 6, dez.1978.

Entrevista. Pasquim, Rio de Janeiro, n. 468, p. 1-

Só a nação poderá sepultar o ATO 5. O Estado de S. Paulo, 13 dez, 1978a.Supl. Especial, p.12.

. Os etéreos programas dos partidos. Isto É, São Paulo, n. 159, p. 7, 02 jan.1980.

. O poder do segredo. Isto É, São Paulo, n. 181, p. $\overline{19,11}$ jun.1980a.

Assembléia Constituinte: a legitimidade recuperada. São Paulo: Brasiliense, 1981.

A guerra dos Orixás. Isto É, São Paulo, n.212, $\overline{\text { p.14, } 14}$ jan. $1981 \mathrm{a}$ 
. O nordeste em questão: acertando as contas com a velha hegemonia. Isto É, São Paulo, n.215, p.17, 4 fev.1981b.

O chefe e a sombra. Isto É, São Paulo, n. 216, p. $\overline{17,11}$ fev.1981c.

Os resíduos da transição. Isto É, São Paulo, n. 221, p. 21, 18 mar.1981d

Só o futuro o dirá. Isto É, São Paulo, n. 220, p. $\overline{13,11}$ mar.1981e.

Quem acredita na democracia. Isto É, São Paulo, n. 230 , p. 15,20 maio $1981 \mathrm{f}$.

Uma conta extravagente. Senhor, São Paulo, n. 339, p. 33,15 set. 1987.

A constituinte em repouso. IstoÉ/Senhor, São Paulo, n. 982, p. 33, 11 jul.1988.

A constituição à vista. IstoÉ/Senhor, São Paulo n. 990, p. 25, 07 set.1988a.

A lei do São-nunca. IstoÉ/Senhor, São Paulo, n. 991, p. 35, 14 set.1988b.

Machado de Assis: a pirâmide e o trapézio. Rio de Janeiro: Globo, 1998.

Os donos do poder: formação do patronato político brasileiro. Rio de Janeiro: Globo, 1998a.

Mais subproduto das trapalhadas. Isto É/Senhor São Paulo, n. 1082, p. 19, 13 jun.1990

Os afilhados do artigo $7^{\circ}$. Isto É/Senhor. São Paulo, n.1092, p. 21, 22 ago.1990a

Inovar não é reformar, nem mudar. Isto É/Senhor. São Paulo, n. 1093, p. 25, 29 ago.1990b.

Entrevista. Isto É/Senhor. São Paulo, n. 1064, p. 3-12, 07 fev.1990c

O Plano: o improviso e a incerteza. IstoÉ/Senhor, São Paulo, n. 1.071, 28 mar.1990d

A corrupção que não aparece. Revista IstoÉ/Senhor, n.1160, p. 33, 18 dez. 1991.

Enquanto o senhor lobo não vem. Isto É/Senhor, São Paulo, n.1140, p.27, 31 jul.1991a.

. A pata do centralismo. Isto É/Senhor. São Paulo:

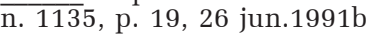

O jogo em três dimensões. IstoÉ/Senhor. São Pauo: n. 1166, p. 15, 05 fev. 1992

Um inventário do Caos. IstoÉ/Senhor. São Paulo: n.1173, p. 31, 25 mar.1992a.

Um detalhe na arte de furtar. Isto É. São Paulo: $\overline{\text { n. } 1174}$, p. 21, 01 abr.1992b.

O difícil e estéril aprendizado. Isto É. São Paulo: n.1175, p. 23, 08 abr. $1992 \mathrm{c}$

Onde está o liberalismo. Isto É. São Paulo: n. 1178, p.21, 29 abr. 1992 d.

- A fronteira da recessão. Isto É. São Paulo: n. 1181, p.21, 20 maio 1992e.

O desafio pessoal e o constitucional. IstoÉ. São Paulo: n. 1182, p. 25, 27 maio $1992 \mathrm{f}$

Governabilidade à brasileira. Isto É, São Paulo, $\overline{\mathrm{n} .1226}$, p. 25, 31 mar.1993

Temida e temível revisão. Isto É, São Paulo, n.1227, p. 25, 07 abr.1993a

Existe um pensamento político brasileiro? São
Paulo, Ática, 1994.

Entrevista. Carta Capital, São Paulo, n.25, set.1995. In: DIAS, Maurício (Org.) Entrevistas Raymundo Faoro: a democracia traída. São Paulo, Globo, 2008. p. 201-218.

Um muro secular entre a mão e a espiga. Carta Capital, São Paulo, n. 13, p. 60, ago.1995a

O terremoto como critério de governo. Carta $\mathrm{Ca}$ pital, São Paulo, n. 16, p. 24, nov.1995b

Entrevista. Carta Capital, São Paulo, n. 31, 29 mar.1996. In: DIAS, Maurício (Org.) Entrevistas Raymundo Faoro: a democracia traída. São Paulo, Globo, 2008. p. 219-233.

A santidade do casuísmo. Carta Capital, São Pauo, n. 39, p. 31, 25 dez. 1996a

Milagres da voz rouca. Carta Capital, São Paulo, n. 42, p. 31, 19 fev.1997.

Entrevista. Carta Capital, São Paulo, n.46, 25 jun. 1997. In: DIAS, Maurício (Org.) Entrevistas Raymundo Faoro: a democracia traída. São Paulo: Globo, 2008. p. $235-251$

FHC caiu na vida: entrevista. Carta Capital, São Paulo, n. 77, 24 jun 1998. In: DIAS, Maurício (Org.) Entrevistas Raymundo Faoro: a democracia traída. São Paulo: Globo, 2008. p. 253-267.

Mais um bando de neobobos. Carta Capital, São Paulo, n.83, p.26, 30 set. 1998a

O desabafo de Faoro: entrevista. Isto É, São Paulo, n.1657, p.10, 04 jul. 2001

Entrevista. Folha de S. Paulo, 14 maio 2000. Caderno Mais, p. 6-13.

FURTADO, C. Brasil, a construção interrompida. São Paulo: Paz e Terra, 1992.

Entrevista. Rio de Janeiro: Eduerj, 2002. (Coleção pensadores contemporâneos)

Cientelismo e modernidade. In: Seca e poder. São Paulo: Fundação Perseu Abramo, $\overline{1998 . p}$. 52-56.

JEFFERSON, T. Escritos políticos. São Paulo: Abril Cultural, 1979. p. 3-40. (Série os pensadores)

LAMOUNIER, B. Reflexões sobre o futuro da política e da democracia. Ciências Sociais na Atualidade. São Paulo, Paulus, p. 13-32, 2009

MENEGUIM, F. B.; BUGARIN, M. Reeleição e política fiscal: um estudo dos efeitos nos gastos públicos. Economia Aplicada, São Paulo, v. 5, n. 3, p. 600-622, 2001.

MORAN, C. A.A.; WITTE, G. A conceituação de inflação e uma análise dos planos econômicos brasileiros de 19701990. Teoria Evidência Econômica, Passo Fundo-RS, n. 1, p. 119-141, mar., 1993

PEREIRA, R. R. Entrevistador In: FURTADO, C. Seca e poder. São Paulo: Fundação Perseu Abramo, 1998. p. 52-56.

REZENDE, M. J. de. A circularidade do autoritarismo no Brasil: a leitura do jurista Raymundo Faoro sobre alguns impasses políticos vindos à tona na década de 1990. Reflexión Política, Bogotá, n. 22, p. 17-33, dez. 2009.

Alguns embaraços do projeto de abertura política no Brasil que foram apontados por Raymundo Faoro. $\mathrm{Ci}$ ências Sociais na Atualidade. São Paulo, Paulus, p. 133164, 2009.

Las dificultades para desmontar las prácticas autoritárias en Brasil: el análisis de Raymundo Faoro sobre el inicio del proceso de ‘apertura' política en 1980. POLIS, México, Universidad Autónoma Metropolitana de Iztapalapa, v. 5, n. 2, p. 49-77, 2009a. 
A história da democracia ainda não começou no Brasil, afirmava o jurista Raymundo Faoro no início da década de 2000. Nómadas: revista crítica de Ciencias sociales y jurídicas. Madrid,Universidad Complutense de Madrid, n. 24, p. 329-342, dez., 2009b.

O penúltimo ano do governo Sarney expondo o malogro da transição política brasileira: a análise de Raymundo Faoro. Ensaios FEE, Porto Alegre, v. 29, n. 1. p. 179-206, 2008.

A interpretacão de Raymundo Faoro acerca dos procedimentos não-democráticos do governo Collor: um análise da transição política brasileira nos anos de 1991 e 1992. Iberoamericana, Berlim/Madrid, n. 23, p. 35-54. 2006

As reflexões de Raymundo Faoro sobre a transicão política brasileira nos anos 1989 e 1990. Política \& Sociedade. Florianópolis, v. 5, n. 09, p. 91-121, 2006a.
O capitalismo brasileiro e as modernizações desvinculadas da modernidade. Ensaios FEE, Porto Alegre, v. 27, n. 1, p. 207-233, 2006b. liação In: . A transição como forma de dominação política. Londrina, Eduel, 1996. p. 138-156.

ROMERO, S. Nosso maior mal. In: Provocações e debates: contribuicões para o estudo do Brasil social. Porto, Chardron de Lello \& Irmão, 1910. p. 10-19

WEBER, M. Economia e sociedade: fundamentos da sociologia compreensiva. Brasília, DF: UNB, 1999, 1999. 580p. v. 2 , 


\section{A SUBSTANTIALITY OF OLIGARCHIC PROCEDURES IN BRAZIL BETWEEN 1995 AND 1998: the Faoro Analyses}

\author{
Maria José de Rezende
}

This study maps the reflections of Raymundo Faoro, in the second half of the 1990s, based on interviews and published papers by the author in the Carta Capital magazine, about the continuity or not of the political procedures that reaffirm the difficulties of the creation of more enduring practices in the consolidation of democracy in the country. The analysis of these journalistic materials, taken as documents, elucidates some fundamentals of the clashes waged, in the 1990s, by various social groups present in the political arena.

KEYwORDS: democracy, oligarchy, authoritarianism, political change and reform.

\section{LA CONSISTANCE DES PROCÉDÉS OLIGARCHIQUES AU BRÉSIL ENTRE 1995 ET 1998: les analyses de Faoro}

\section{Maria José de Rezende}

Cette étude systématise les réflexions de Raymundo Faoro, dans la deuxième moitié de la décennie de 1990, en se basant sur les articles et les interviews publiés par l'auteur dans la revue Carta Capital concernant la poursuite ou non des procédés politiques qui réaffirment les difficultés rencontrées pour constituer des pratiques plus durables de consolidation de la démocratie dans le pays. L'analyse de ce matériel journalistique, considéré comme document, éclaire certains aspects fondamentaux des affrontements qui ont eu lieu dans les années 1990 au sein de divers groupes sociaux présents dans l'arène politique.

Mots-CLÉs: démocratie, oligarchie, autoritarisme, changement politique, réformes.

Maria José de Rezende - Doutora em Sociologia pela Universidade de São Paulo. Professora de Sociologia da Universidade Estadual de Londrina. Atua nas linhas de pesquisa: Estado e democracia no Brasil, pensamento social e político brasileiro, política brasileira, teorias da mudança social, desigualdades e exclusões no Brasil hoje. Desenvolve o projeto de pesquisa intitulado "A multidimensionalidade das teorias da mudança social no Brasil“. Autora dos livros A transição como forma de dominação política (1996) e Ditadura militar no Brasil (2001), ambos pela editora Eduel. Co-autora de outros livros, tais como Direitos humanos e educação (2005) pela editora Cortez. Já publicou alguns artigos sobre Faoro, tais como: O capitalismo brasileiro e as modernizações desvinculadas da modernidade. Ensaios FEE, v. 27, n. 1 e A interpretação de Raymundo Faoro acerca dos procedimentos não-democráticos do governo Collor de Mello: uma análise da transição política brasileira nos anos de 1991 e 1992. Iberoamericana, n. 23, Berlim, Vervuert. 